\title{
MULTI-CRITERIA GREY RELATIONAL APPROACH TO EVALUATING RECONFIGURABLE MANUFACTURING CONFIGURATIONS
}

\author{
A.U. Rehman ${ }^{1 *}$
}

\section{ARTICLE INFO}

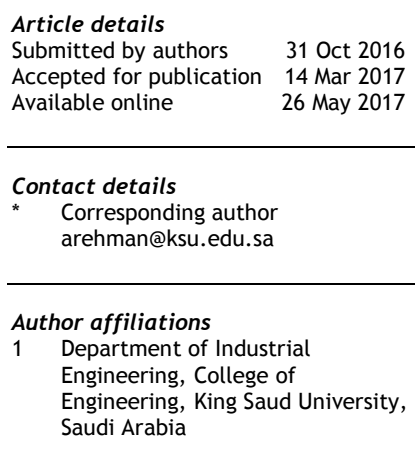

DOI

http://dx.doi.org/10.7166/28-1-1681
ABSTRACT

In response to highly dynamic markets, manufacturing industries need alternative feasible manufacturing strategies. The strategy currently adopted is to reconfigure the existing manufacturing system. The conditions to reconfigure existing configurations change from time to time. An attempt is made to identify and apply an approach to evaluate these configurations. The paper proposes a grey relational decision-making approach. The approach takes into account multiple performance measures. The ProModel 6.2 simulation platform is adopted to examine the performance of each feasible alternative manufacturing configuration.

\section{OPSOMMING}

Vervaardigingsindustrieë het alternatiewe, uitvoerbare vervaardiging-strategieë nodig om by die hoogs dinamiese markte aan te pas. Die huidige strategie is om die bestaande vervaardigingstelsel te herkonfigureer. Die omstandighede om bestaande konfigurasies te herkonfigureer verander met tyd. 'n Poging word gemaak om 'n benadering te identifiseer en toe te pas om hierdie konfigurasies te evalueer. 'n Grys-verwante besluitmakingsbenadering word voorgestel. Die benadering neem veelvuldige vertoningsmaatstawwe in ag. Die ProModel 6.2 simulasie platform is gebruik om die vertoning van elke uitvoerbare alternatiewe vervaardiging konfigurasie te ondersoek.

\section{INTRODUCTION}

There are dynamic changes in the contemporary scenario of market demand. Traditional manufacturing hardware and software components fail to satisfy competitive market requirements when needed. In response to this, Lee [1] initiated a consideration of configurability in the design of manufacturing system components. Recently, researchers [2-3] have stressed the need to reconfigure the manufacturing system when needed to cater for market dynamics. It is evident that manufacturers do change current manufacturing configurations. For example, changes in manufacturing capacity and sequence [4], grouping of machines, and retrofitting of machines are common reconfigurations to the manufacturing system [5]. Ahmed and ElMaraghy [6] reported reconfiguring a manufacturing system through the agile design of system components. But market dynamics require reconfiguration with minimal effort, at short notice, and at a competitive cost [7]. To deal with these requirements, there are developments in reconfigurable machines [8] and reconfigurable assembly systems [9]. Fu-Shiung [10] presented a reconfiguration mechanism to accommodate changes without causing chaos on the shop floor. Fu-Shiung and Chiang [11] provided an operational framework to deal with dynamic reconfiguration, while Ibrahim [12] presented an approach to generate reconfigurable manufacturing configurations, as an optimisation problem.

However, industry decision-makers need to evaluate feasible alternatives before undertaking reconfiguration. As decision-makers, they may need to say 'yes' or 'no' to a particular option - and justify their decision. For this, they have to do a comparative analysis of the alternatives, based on multiple performance parameters. An attempt is made in this paper in this direction. 
The paper is organised in five sections. Section 2 presents a brief review of manufacturing system reconfiguration and decision analysis. The theoretical background related to the grey relational decision-making approach is presented in Section 3. The manufacturing system and reconfiguration alternatives adopted in response to market dynamics are presented in Section 4. For each alternative, simulation models are developed for performance analysis under various operational scenarios. Subsequently, the comparative analysis of feasible alternatives using the multi-criteria grey relational approach is done. The approach application that is adopted is also presented in Section 4. The paper concludes with Section 5.

\section{RECONFIGURATION OF MANUFACTURING SYSTEM: A BRIEF REVIEW}

A reconfigurable manufacturing system (RMS) is a manufacturing system that is designed at the outset to make changes in the structure (and in the hardware and software components) in order to adjust production capacity and functionality quickly in response to sudden changes in market requirements [2]. An RMS that reacts quickly and effectively to dynamic market demands through the modular and scalable design of the manufacturing system on the system level and on the machine level $[4,6]$. An RMS approach is the manufacturing system that is flexible enough to manufacture a group of products at low cost, with a set of customised and diagnostic characteristics: modularity, scalability, interchangeability, and convertibility [7]. An RMS has both conventional flexible machines and a new type of machine - called the reconfigurable machine [8] - on its production line.

For a quick response to a dynamic market, researchers proposed reconfiguring the manufacturing system. According to Renna and Ambrico [13], reconfiguration means a modification in capability and functionality to accommodate dynamic fluctuations in market demand. Bi, Lang, Zen and Wang [14] and Rehman and Babu [15] highlighted the concept and applications relevant to reconfiguration of the manufacturing system, while Padayachee and Bright [8] focused on reconfigurable machine control hardware and software. Tang, Bi and Qiu [16] presented an integrated design approach for the virtual reconfiguration of a production line. Youssef and ElMaraghy [7] evaluated modular production lines based on expected production rates. Similarly, Landers, Min and Koren [17] designed reconfigurable modular machines to allow reconfiguration according to changes in production plan. At a machine level, logical reconfiguration in machine supervisory control is proposed by Schmidt [18]. Similarly, researchers presented a collaborative reconfiguration mechanism for a reconfigurable parallel machining system [19], for a responsive manufacturing system [20], and for an holonic manufacturing system [21]. At machine, process, and control levels, game theory techniques [22], genetic algorithms [23], and a fuzzy approach [24] are used for decision analysis. Recently, to minimise inventory level and throughput time, a stochastic model for logical reconfiguration has been proposed [25].

Literature reviews over the past two decades reveal that manufacturing industries need alternative feasible manufacturing strategies for dynamic internal and external demand. Researchers have proposed reconfiguring the existing manufacturing system. But conditions to reconfigure existing configurations change from time to time. Assessing these alternatives needs to take multiple performance criteria into account. So there is a need to identify and apply an approach to assess alternate configurations. This paper proposes a grey relational decision-making approach. The theoretical background is presented in the next section.

\section{ADOPTED MULTI-CRITERIA APPROACH}

In any industrial organisation, multiple attributes or objectives are considered in a decision analysis. There might be multiple alternatives to exactly the same state of affairs. Researchers and practitioners adopted multi-criteria decision analysis in a number of industrial applications - for example, using a fuzzy approach in manufacturing technology investment decisions [26-27], or using a fuzzy analytical hierarchy approach [28-29] and a concordance approach [30-31] to evaluate alternatives. At machine-level reconfiguration, Galan, Racero, Eguia and Garcia [32] used a product feature-based decision approach. To optimise production planning in the case of reconfigurable production lines, Abbasi and Houshmand [33] used genetic algorithms.

The comparative analysis of feasible manufacturing alternatives, and making the right choice among these alternatives, can be discreet in nature. Simulation tools [34] are preferred to simulate and 
analyse manufacturing and service systems of all types and sizes. For multi-criteria situations in the manufacturing and service industry [35-36], researchers used an analytic hierarchy [37] and a nonstructural fuzzy approach [38]. An analytic hierarchy process focuses on a pairwise comparative assessment. Subsequent researchers used algorithms/models such as elimination and choicetranslating algorithms [30], preferences based on a similarity index [39], a Promethee and Gaia approach [40], and a superiority and inferiority ranking [41] where the multi-criteria decision analysis is handled properly. But these multi-criteria decision analysis models are not sensitive to small deviations in multiple controlling measures. In order to overcome this challenge, a grey relational grade approach [42-44] is proposed. Grey relational analysis is applied in various fields, such as decision-making [44], machining science [45-47], manufacturing strategies [48], and product development strategies [49-50]. A grey relational grade approach is one where two alternatives are compared, based on global and local sets of data points. The primary motivation for using a grey relational grade approach is that one can involve the decision-makers at every stage. However, there are some apprehensions about the grey relational grade approach. For example, the variation in grey grade relational values for any two alternatives is very small; in such cases, further analysis is recommended. Details of the steps in a grey relational decision approach are presented in the next subsection.

\subsection{Steps in a grey relational decision approach}

The approach of a 'grey relational decision' has five steps that compare and rank a finite number of decision alternatives.

\section{Step 1: Construction of a decision matrix}

The decision-maker defines a set of alternatives and criteria to be evaluated. For each criterion, a preference index is assigned. In each case, the criterion is to be maximised (the higher the better), and the preference index value is one or zero. To formulate the decision matrix ' $D M$ ', one must enter response values for each criterion. The matrix ' $D M$ ' is formulated as follows:

$D M=\left[y_{j k}\right]=\left[\begin{array}{ccc}y_{11} & \cdots & y_{m 1} \\ \vdots & \ddots & \vdots \\ y_{1 c} & \cdots & y_{m c}\end{array}\right]$

where ' $y_{j k}$ ' is the response value, and ' $j$ ' and ' $k$ ' represent the alternative and the criterion respectively. ' $\mathrm{j}$ ' varies from 1 to ' $\mathrm{m}$ ' alternatives, and ' $\mathrm{k}$ ' varies from 1 to ' $c$ ' criteria.

\section{Step 2: Normalisation of a decision matrix}

Using Equations 1 and 2 below, a normalised decision matrix (NDM) is derived for the corresponding criterion related to each alternative. Eqation 1 is used where the criterion objective is minimisation. Equation 2 is used for the maximisation criterion.

$$
\begin{gathered}
y_{j k}^{\prime}=\frac{\max \left(y_{j k}\right)-y_{j k}}{\max \left(y_{j k}\right)-\min \left(y_{j k}\right)} \\
y_{j k}^{\prime}=\frac{y_{j k}-\min \left(y_{j k}\right)}{\max \left(y_{j k}\right)-\min \left(y_{j k}\right)} \\
N D M=\left[y_{j k}^{\prime}\right]=\left[\begin{array}{ccc}
y_{11}^{\prime} & \cdots & y_{m 1}^{\prime} \\
\vdots & \ddots & \vdots \\
y_{1 c}^{\prime} & \cdots & y_{m c}^{\prime}
\end{array}\right]
\end{gathered}
$$

Step 3: Derive preference sequence

Preference sequence ' $y_{o k}$ ' is obtained using Equation 3.

$$
y_{o k}=\left\{\begin{array}{c}
\min _{\forall j}\left\{y_{j k}\right\} \text { for smaller the best } \\
\max _{\forall j}\left\{y_{j k}\right\} \text { for larger the best }
\end{array}\right.
$$

After comparing each alternative with reference to the preference sequence, the grey relational coefficient is calculated.

Step 4: Calculate grey relation co-efficient

Grey relational co-efficient ' $\gamma_{j k}$ ' is calculated using Equation 4. 


$$
\gamma_{j k}=\frac{\min \left(\Delta_{j k}\right)+\rho \max \left(\Delta_{j k}\right)}{\Delta_{j k}+\rho \max \left(\Delta_{j k}\right)}
$$

In Equation 4, ' $\mathrm{j}$ ' varies from 1 to ' $m$ ' alternatives (manufacturing configurations), and ' $k$ ' varies from 1 to ' $c$ ' criteria (performance measures). And $\rho$ is the user-selected resolution coefficient that lies between zero and one. It is the contrast controller.

According to Wen [44], $\rho=0.5$ is normally applied. $\Delta_{j k}$ is the absolute difference between $y_{o k}$ for the performance measure ' $\mathrm{k}$ ', and $y_{j k}$ is the response value corresponding to alternative ' $\mathrm{j}$ ' for the performance measure ' $\mathrm{k}$ '. Thus $\Delta_{j k}$ is calculated using Equation 5.

\section{Step 5: Calculate 'grey relation grade' value}

$$
\Delta_{j k}=A b s\left(y_{o k}-y_{j k}\right)
$$

The grey relational grade value ' $\overline{\gamma_{j}}$ ' for an alternative over all criteria, is calculated by using Equation 6 , which is given below.

$$
\overline{\gamma_{J}}=\frac{1}{c} \sum_{k=1}^{c} \gamma_{j k}
$$

In Equation 6, $\bar{\gamma}_{J}$ represents the grey relation grade value for manufacturing configuration alternative ' $\mathrm{j}$ ', and $\gamma_{j k}$ is the grey relational measurement corresponding to manufacturing configuration ' $\mathrm{j}$ ' and performance measure ' $k$ '. This equation is for equal weighting for all criteria. Where unequal weightings for each performance criteria are considered, Equation 6 above is extended to Equation 7.

$$
\bar{\gamma}_{j}=\sum_{j=1}^{m} \beta_{k} \gamma_{j k}
$$

In Equation 7, $\beta_{k}$ denotes the normalised weighting for each performance criterion.

The approach presented above converts a multiple-attribute decision situation into a singleattribute decision. The grey relational grade value reveals how close a manufacturing configuration alternative is to the ideal configuration. The existing manufacturing system and the reconfiguration alternatives adopted in response to market dynamics are presented in the next section. The adopted application for the approach is also presented.

\section{MANUFACTURING CONFIGURATIONS AND SIMULATION MODEL}

The research work relates to an industry that produces a product mix of auxiliary parts using conventional machines. These conventional machines are arranged in a process type of manufacturing configuration. There are product mix orders of random quantities. To survive in a dynamic market, operation managers are considering a reconfiguration of the existing manufacturing configuration; and it is important that the new manufacturing configuration (after reconfiguration) should respond quickly to market dynamics. Initially the industry manager draws up an effective demand-capacity plan, production scheduling, material requirement planning, inventory policies, and manufacturing resource planning. But to match the market dynamics, it was proposed to combine the existing conventional machines with advanced computer-controlled reconfigurable machines/machine tools (RMT), or even with groups of RMTs. Once any product goes to RMT, the RMT will take care of the product required set of process operations. RMTs have multiple functional flexibilities $[8,17]$. A computer program and reconfigurable tools take care of the required process sequence and operations. Based on the dynamic product mix demand, alternative configurations were identified for the current configuration. Thus, five configurations in total are identified here as 'config1' to 'config5' and presented in Table 1. The framework was developed to evaluate and rank the configurations, taking multiple performance measures into account.

\subsection{Simulation model}

A powerful Windows-based ProModel 6.2 simulation tool is used to simulate and analyse manufacturing systems of all types and sizes [34]. The simulation tool views a manufacturing system as an arrangement of processing locations, such as machines or workstations, through which products or entities are processed according to defined processing and routeing logic. The basic building blocks for the simulation model are called modules. The simulation model consists of five modules. The 'entity module' defines various entities. The 'location module' defines the physical and logical locations and relationships where the processes are performed. The 'process and routeing module' deals with identifying the processes that are required for the products and their routeing. The 'pathnetwork module' is used to show nodes or places through which entities (i.e., products) move from 
location to location, or where they arrive or leave the model. The 'user-defined module' helps to define variables, attributes, arrays, and external data. The model is simulated for a number of operational conditions. For each alternative, simulation models are developed to do performance analysis under twenty-four identified operational scenarios (see Table 2). These scenarios are used to simulate the configuration modules.

For all operational scenarios (see Table 2 above) and for all configurations (see Table 1 above), simulation models were designed and executed. After each simulation run, corresponding multiple performance measure values are imported as output values. The sample simulation output is presented in Table 3.

Table1: Alternative manufacturing system configuration types and their codes

\begin{tabular}{|l|l|l|}
\hline Types & Code & Note \\
\hline $\begin{array}{l}\text { Present } \\
\text { configuration }\end{array}$ & Config1 & $\begin{array}{l}\text { This configuration has five process types of manufacturing areas. They have } \\
\text { seventeen conventional machines (CMS) arranged in a process type of } \\
\text { layout. }\end{array}$ \\
\hline \multirow{4}{*}{$\begin{array}{l}\text { Alternative } \\
\text { configurations }\end{array}$} & Config2 & $\begin{array}{l}\text { This configuration has two advanced computer-controlled reconfigurable } \\
\text { machine tools (RMTs) arranged in parallel, and seven conventional machines } \\
\text { arranged in a process type of layout. }\end{array}$ \\
\cline { 2 - 3 } & Config3 & $\begin{array}{l}\text { This configuration has two advanced computer-controlled reconfigurable } \\
\text { machine tools (RMTs) arranged in parallel, and twelve conventional } \\
\text { machines arranged in a process type of layout. }\end{array}$ \\
\cline { 2 - 3 } & Config4 & $\begin{array}{l}\text { This configuration has one advanced computer-controlled reconfigurable } \\
\text { machine tool (RMT) arranged in parallel, and twelve conventional machines } \\
\text { arranged in a process type of layout. }\end{array}$ \\
\cline { 2 - 3 } & Config5 & $\begin{array}{l}\text { This configuration has seventeen advanced computer-controlled } \\
\text { reconfigurable machine tools (RMTs) arranged in parallel. }\end{array}$ \\
\hline
\end{tabular}

Table 2: Operational scenarios cosidering various operational parameters

\begin{tabular}{|c|c|c|}
\hline $\begin{array}{c}\text { Operational } \\
\text { parameter (code) }\end{array}$ & Levels & Detail \\
\hline Arrival pattern of customers $(\mathrm{E})$ & $\begin{array}{l}2 \\
(E 3 \& E 4)\end{array}$ & $\begin{array}{l}\text { E3 -Estimated three days between two customer } \\
\text { arrivals; and } \\
\text { E4 -Estimated four days between two customer } \\
\text { arrivals. }\end{array}$ \\
\hline Arrival pattern of orders $(0)$ & $\begin{array}{l}3 \\
(01,02 \& 03)\end{array}$ & $\begin{array}{l}\text { O1 -Average one set of product mix order per } \\
\text { customer } \\
\text { O2 -Average two sets of product mix order per } \\
\text { customer; and } \\
\text { O3 -Average three sets of product mix order orders } \\
\text { per customer }\end{array}$ \\
\hline Priority rules $(\mathrm{P})$ & $\begin{array}{l}2 \\
(P 1 \& P 2)\end{array}$ & $\begin{array}{l}\text { P1 -Order scheduling policy of first-come, first- } \\
\text { served; and } \\
\text { P2 -Order scheduling policy of shortest processing } \\
\text { time first }\end{array}$ \\
\hline Lot size (L) & $\begin{array}{l}2 \\
(L 1 \& L 2)\end{array}$ & $\begin{array}{l}\text { L1 - Lot size of twenty-five products } \\
\text { L2 -Lot size of fifty products }\end{array}$ \\
\hline \multicolumn{3}{|c|}{$\begin{array}{l}\text { Note: There are } 2 \times 3 \times 2 \times 2=24 \text { operational scenarios. For example, Scenario } 1 \text { 'E301P1L1' denotes an } \\
\text { operational scenario, with an estimated three days between two customer arrivals, and an average of one } \\
\text { set of product mix orders per customer. These orders are scheduled using the 'first-come, first-served' } \\
\text { priority rule, and a lot size of twenty-five products is opted for. }\end{array}$} \\
\hline
\end{tabular}

Table 3: Performance measures for operational scenario 'E301P1L1'

\begin{tabular}{|l|l|l|l|l|l|}
\hline \multirow{2}{*}{ Configurations $\downarrow$} & Performance measure & \multicolumn{4}{l|}{} \\
\cline { 2 - 6 } & PM1 (\%) & PM2 (Hrs) & PM3 (Hrs) & PM4 (Hrs) & PM5 (Hrs) \\
\hline Config1 & 80.485 & 169.121 & 477.290 & 122.863 & 433.889 \\
\hline Config2 & 84.539 & 31.185 & 1618.766 & 1133.786 & 1537.597 \\
\hline Config3 & 88.228 & 295.078 & 271.228 & 31.456 & 641.867 \\
\hline Config4 & 88.006 & 98.705 & 660.743 & 237.154 & 633.754 \\
\hline Config5 & 65.031 & 457.835 & 78.725 & 1.352 & 68.404 \\
\hline $\begin{array}{l}\text { Note: Performance measures: PM1: system utilisation, PM2: total cycle time, PM3: number of hours finished } \\
\text { goods delivered prior to due time, PM4: number of hours finished goods delivered late after due time, and } \\
\text { PM5: number of hours for which products wait prior to processing, inspection, and move. }\end{array}$ \\
\hline
\end{tabular}


As shown in Table 3, for a given performance measure, one can see differences in values corresponding to alternative configurations. Not a single alternative outperforms in all five measures. For selected performance measures, the selective manufacturing configuration score is better than the others. In other words, no single configuration yields the best overall performance measures. Considering the multiple-attribute decision situation presented above, the application of the approach adopted to evaluate and rank these configurations is presented in next sections.

\subsection{Application of the adopted approach}

For each alternative, simulation models are developed and executed to carry out a performance analysis under twenty-four operational scenarios (see Table 2). The grey relation analysis approach is adopted to rank these alternative configurations. Using the simulation outcomes (see Table 3), a decision matrix 'DM' for Operational Scenario 1 (i.e., E301P1L1) is constructed as follows:

$$
\begin{aligned}
D M_{\text {Scenario } 1}=\left[y_{j k}\right]_{\text {Scenario } 1} & \\
& =\left[\begin{array}{cccccc}
\downarrow j k \rightarrow & P M 1(\%) & P M 2(h r s) & P M 3(h r s) & P M 4(h r s) & P M 5(h r s) \\
\text { Config1 } & 80.485 & 169.121 & 477.290 & 122.863 & 433.889 \\
\text { Config2 } & 84.539 & 31.185 & 1618.766 & 1133.786 & 1537.597 \\
\text { Config3 } & 88.228 & 295.078 & 271.228 & 31.456 & 641.867 \\
\text { Config4 } & 88.006 & 98.705 & 660.743 & 237.154 & 633.754 \\
\text { Config5 } & 65.031 & 457.835 & 78.725 & 1.352 & 68.404
\end{array}\right]_{\text {Scenario } 1}
\end{aligned}
$$

Likewise, decision matrices for each scenario (see Table 2) were constructed.

Using Equation 1 and Equation 2, the decision matrix for Scenario 1 is converted to a normalised decision matrix (NDM).

$$
N M_{\text {Scenario } 1}=\left[y_{j k}^{\prime}\right]_{\text {Scenario } 1}=\left[\begin{array}{llllll}
\downarrow j k \rightarrow & P M 1 & P M 2 & P M 3 & P M 4 & P M 5 \\
\text { Config1 } & 0.6662 & 0.3233 & 0.7412 & 0.8927 & 0.7512 \\
\text { Config2 } & 0.8409 & 0.0000 & 0.0000 & 0.0000 & 0.0000 \\
\text { Config3 } & 1.0000 & 0.6185 & 0.8750 & 0.9734 & 0.6097 \\
\text { Config4 } & 0.9904 & 0.1583 & 0.6221 & 0.7918 & 0.6152 \\
\text { Config5 } & 0.0000 & 1.0000 & 1.0000 & 1.0000 & 1.0000
\end{array}\right]_{\text {Scenario } 1}
$$

Similarly, normalised decision matrices for each scenario (see Table 3) were constructed. Five performance measures are considered, among them three performance measures whose objective criteria is minimisation, while the remaining two have the objective of maximisation. The preference sequence $y_{o k}$ is obtained using Equation 3.

$$
\left.y_{o k}=\begin{array}{llllll}
\text { For minimisation criteria } & {[0} & 0 & 1 & 1 & 1
\end{array}\right] \text { For maximisation criteria }\left[\begin{array}{lllll}
1 & 1 & 0 & 0 & 0
\end{array}\right]_{\text {for all scenarios }}
$$

Subsequently, using Equation 4, the grey relation co-efficient matrix is obtained for Operational Scenario 1 as follows:

$$
\gamma_{j k}=\left[\begin{array}{llllll}
\downarrow j k \rightarrow & P M 1 & P M 2 & P M 3 & P M 4 & P M 5 \\
\text { Config1 } & 0.5997 & 0.4249 & 0.6589 & 0.8233 & 0.6678 \\
\text { Config2 } & 0.7587 & 0.3333 & 0.3333 & 0.3333 & 0.3333 \\
\text { Config3 } & 1.0000 & 0.5672 & 0.8000 & 0.9495 & 0.5616 \\
\text { Config4 } & 0.9812 & 0.3726 & 0.5695 & 0.7060 & 0.5651 \\
\text { Config5 } & 0.3333 & 1.0000 & 1.0000 & 1.0000 & 1.0000
\end{array}\right]_{\text {Scenario } 1}
$$

Then calculate the grey relational grade value ' $\bar{\gamma}_{J}$ ' for each configuration over all criteria using Equation 7 above. For example, the calculated ' $\bar{\gamma}_{J}$ ' (for Operational Scenario 1 'E301P1L1') is presented in the following matrices. 


$$
\bar{\gamma}_{J}=\left[\begin{array}{cc}
\downarrow j & \text { Grey relation grade } \\
\text { Config1 } & 0.1270 \\
\text { Config2 } & 0.0837 \\
\text { Config3 } & 0.1551 \\
\text { Config4 } & 0.1278 \\
\text { Config5 } & 0.1733
\end{array}\right]_{\text {Scenario 1 }}
$$

Here normalised equal weights are considered for each criterion. Thus, the grey relational analysis based on alternative manufacturing configuration rankings is obtained for Scenario 1, and is presented as below.

$$
\text { Configuration rank for scenario } 1=\left[\begin{array}{cc}
\downarrow j & \text { Rank } \\
\text { Config1 } & 4 \\
\text { Config2 } & 5 \\
\text { Config3 } & 2 \\
\text { Config4 } & 3 \\
\text { Config5 } & 1
\end{array}\right]
$$

For 'E301P1L1' (which denotes Operational Scenario 1), as presented in the matrix above, the manufacturing configurations Config5, Config3 and Config4 demonstrate better ranking than the existing Config1. And Config2 is found to be worse when compared with all four other configurations. The final decision between Config5 and Config 3 depends on multiple operational constraints. From the grey relational coefficient matrix, it is noted that Config4 and Config3 perform better on the performance measure system utilisation 'PM1', while for the other performance measures, Config 3 and Config5 are exactly the opposite. In order to test the effect of uncertainties in the operational policies on the system performance (of each alternative configuration), a sensitivity analysis is performed. The detail is presented in the next subsection.

\subsection{Sensitivity analysis}

Sensitivity analysis [51] helps to study deviations in the outcome parameters of a model due to deviations in the input parameter values. One needs to establish the effect of a variation in input variable on the output variable. Sensitivity analysis can help the decision-maker to determine which parameters are the key drivers. Here, a sensitivity analysis is done to evaluate the manufacturing configurations by variations in performance criteria weights, resolution coefficients, prioritisation of product-to-load machines, the arrival rate of customers, and their product mix demand. Grey relational grade values for each manufacturing configuration for all operational scenarios and four resolution coefficients (see Table 4) are obtained. Since the collected sensitivity analysis data is enormous, a sample of grey relational grade values for each manufacturing configuration for a few scenarios for four resolution coefficients is presented in Table 5.

Table 4: Performance measure weights for sensitivity analysis

\begin{tabular}{|l|l|l|l|l|l|l|}
\hline$\downarrow$ Weights 'B' & \multicolumn{7}{|l|}{ Performance measure \% weights } \\
\cline { 2 - 7 } & PM1 & PM2 & PM3 & PM4 & PM5 & Weights total \\
\hline Set1 & $20 \%$ & $20 \%$ & $20 \%$ & $20 \%$ & $20 \%$ & $100 \%$ \\
\hline Set2 & $50 \%$ & $20 \%$ & $10 \%$ & $10 \%$ & $10 \%$ & $100 \%$ \\
\hline Set3 & $20 \%$ & $50 \%$ & $10 \%$ & $10 \%$ & $10 \%$ & $100 \%$ \\
\hline Set4 & $22.5 \%$ & $27.5 \%$ & $20 \%$ & $12.5 \%$ & $17.5 \%$ & $100 \%$ \\
\hline Resolution coefficients ' $\rho$ ' : '0< $0 \leq 1$ ' $=\{0.5,0.2,0.8,1.0\}$ \\
\hline Note: ${ }^{\#}$ For performance measures description refer to Table 3 \\
\hline
\end{tabular}

In Table 5 below, one can note that the grey relational grade values are sensitive to changes in the controlling parameters, such as performance measure weights, resolution coefficients, prioritisation of product to load machines, the arrival rate of customers, and their product mix demand. From the sensitivity analysis it is clear that, if the management sets equal weights to all performance measures, 'Config5, Config3 and Config4' is the superior choice over Config1 (present configuration), and Config2 is the worst choice overall. Config4 is a worse choice than either Config5 or Config3. Similarly, if the major weighting is set to performance criteria 'system utilisation (PM1)', the ranking order is found to be Config3, Config4, Config5, Config1, and Config2. The obtained ranking order of the alternative four configurations over the present configuration (Config1), corresponding to 
changes in parameter weights, is presented in Table 6. It is also observed that the order scheduling policy rules and lot sizing do not affect the ranking order. Therefore, as far as the dynamic changes in market demands are concerned, the existing traditional manufacturing configuration (Config1) fails to satisfy the competitive market requirements, and needs to be reconfigured. Decisionmakers' first choice would be Config5, and their second choice would be Config3. The final choice is subject to managerial constraints.

Table 5: Grey relational grade values for each manufacturing configuration for selected scenarios with respect to set of weights ' $B$ ' and each ' $\rho$ ' value

\begin{tabular}{|c|c|c|c|c|c|c|c|c|c|c|c|c|c|c|c|c|c|c|}
\hline & \multirow{2}{*}{\multicolumn{4}{|c|}{$\rho=0.5$}} & \multicolumn{4}{|c|}{$\rho=0.2$} & \multicolumn{4}{|c|}{$\rho=0.8$} & \multicolumn{4}{|c|}{$\rho=1.0$} \\
\hline & & & Set of weight $\beta$ & & & & \multicolumn{4}{|c|}{ Set of weight $\beta$} & \multicolumn{4}{|c|}{ Set of weight $\beta$} & \multicolumn{4}{|c|}{ Set of weight $\beta$} \\
\hline & & & 1 & 2 & 3 & 4 & 1 & 2 & 3 & 4 & 1 & 2 & 3 & 4 & 1 & 2 & 3 & 4 \\
\hline \multirow{5}{*}{ 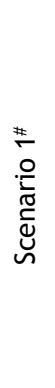 } & \multirow{5}{*}{ 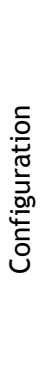 } & - & $\stackrel{*}{\stackrel{*}{\leftrightarrows}}$ & $\stackrel{ }{\dddot{1}}$ & $\stackrel{\circ}{\circ}$ & 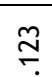 & $\stackrel{\llcorner}{\circ}$ & 今ิ & $\stackrel{\infty}{\circ}$ & o & $\stackrel{0}{\leftarrow}$ & 온 & 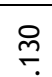 & $\stackrel{\mathscr{m}}{\leftarrow}$ & $\stackrel{t}{\stackrel{t}{n}}$ & $\stackrel{g}{\leftarrow}$ & 욷 & \\
\hline & & N & $\begin{array}{l}\mathbf{1} \\
\text { Dे } \\
0\end{array}$ & $\begin{array}{l}0 \\
\text { ô } \\
0\end{array}$ & $\begin{array}{l}0 \\
\text { 1े } \\
0 \\
0\end{array}$ & $\begin{array}{l}0 \\
0 \\
0 \\
0\end{array}$ & $\begin{array}{l}0 \\
\text { gे } \\
\text { o }\end{array}$ & î́ & $\begin{array}{l}0 \\
\text { gे } \\
\text { o. }\end{array}$ & 员 & $\begin{array}{l}0 \\
0 \\
0 \\
0\end{array}$ & 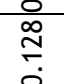 & Oे & $\begin{array}{l}0 \\
\stackrel{0}{\circ} \\
\end{array}$ & $\begin{array}{l}0 \\
\stackrel{2}{\circ} \\
\end{array}$ & $\begin{array}{l}0 \\
\stackrel{0}{\circ} \\
\end{array}$ & 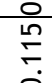 & $\begin{array}{l}0 \\
\stackrel{0}{\circ} \\
\end{array}$ \\
\hline & & $m$ & $\stackrel{n}{\stackrel{n}{L}}$ & $\frac{0}{6}$ & $\stackrel{m}{\tilde{q}}$ & $\stackrel{5}{\circ}$ & $\stackrel{N}{\sim}$ & 윰 & 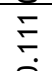 & $\stackrel{\mathscr{n}}{\stackrel{2}{\sim}}$ & $\hat{\circ}$ & $\stackrel{E}{E}$ & $\stackrel{\infty}{\stackrel{\infty}{\circ}}$ & $\stackrel{\circ}{\circ}$ & $\stackrel{5}{N}$ & $\stackrel{\infty}{\leftarrow}$ & ปै & $\frac{5}{n}$ \\
\hline & & t & $\stackrel{\infty}{\sim}$ & 옴 & $\stackrel{m}{\rightleftharpoons}$ & 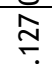 & о & 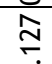 & $\bar{\circ}$ & o & $\stackrel{\text { 年 }}{\leftarrow}$ & 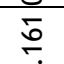 & $\bar{m}$ & J & ก & $\stackrel{\circ}{\circ}$ & $\stackrel{g}{m}$ & in \\
\hline & & n & $\begin{array}{l}0 \\
\stackrel{n}{\hat{0}} \\
\frac{0}{0}\end{array}$ & $\begin{array}{c}0 \\
\stackrel{m}{0} \\
0\end{array}$ & $\begin{array}{l}0 \\
\stackrel{n}{N} \\
0\end{array}$ & $\begin{array}{l}0 \\
\stackrel{0}{2} \\
0 \\
0\end{array}$ & 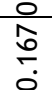 & $\frac{0}{\stackrel{N}{E}}$ & $\begin{array}{l}0 \\
\hat{0} \\
0 \\
0\end{array}$ & n̋ & $\begin{array}{l}0 \\
\stackrel{0}{0} \\
\stackrel{0}{0}\end{array}$ & $\begin{array}{c}\frac{0}{0} \\
\frac{0}{1} \\
\end{array}$ & $\begin{array}{l}0 \\
\stackrel{0}{0} \\
\stackrel{0}{0}\end{array}$ & 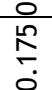 & $\begin{array}{l}0 \\
0 \\
\infty \\
0 \\
0\end{array}$ & $\begin{array}{l}0 \\
\text { 으. } \\
\text { 옹 }\end{array}$ & $\begin{array}{l}0 \\
0 \\
0 \\
0 \\
0\end{array}$ & $\begin{array}{l}0 \\
\stackrel{0}{0} \\
\stackrel{0}{0}\end{array}$ \\
\hline \multirow{8}{*}{ 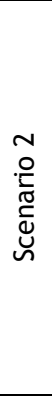 } & \multirow{8}{*}{ 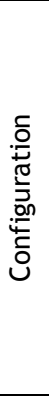 } & - & $\stackrel{\text { Ln }}{\frac{10}{0}}$ & กิ & $\stackrel{\infty}{\stackrel{0}{\sim}}$ & $\stackrel{m}{\leftarrow}$ & $\stackrel{\circ}{ }$ & 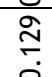 & 음 & $\stackrel{\infty}{\circ}$ & 음 & $\begin{array}{l}\infty \\
\infty \\
0 \\
0\end{array}$ & $\stackrel{\text { In }}{5}$ & 冓 & $\stackrel{0}{\circ}$ & $\stackrel{m}{\stackrel{n}{r}}$ & กี & 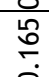 \\
\hline & & N & ڤ్ & E & 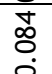 & : & 옹 & 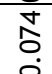 & 옹 & กั & 능 & ָิ & 응 & 응 & $\stackrel{n}{\stackrel{n}{r}}$ & $\stackrel{\hat{m}}{\stackrel{0}{0}}$ & $\stackrel{n}{\check{L}}$ & $\stackrel{N}{E}$ \\
\hline & & 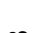 & $\sim$ & $n$ & $\sim$ & - & ᄂ & 5 & 0 & $m$ & $m$ & 우 & $\circ$ & $\approx$ & N & $m$ & $=$ & \\
\hline & & $m$ & $\div$ & $\frac{n}{0}$ & $\stackrel{n}{\circ}$ & $\because$ & $\stackrel{m}{\sigma}$ & $\stackrel{n}{n}$ & $\stackrel{2}{\circ}$ & $\stackrel{m}{\circ}$ & $\overline{0}$ & $\stackrel{\infty}{\circ}$ & $\stackrel{0}{\circ}$ & $\stackrel{1}{\check{r}}$ & $\stackrel{1}{\check{r}}$ & $\stackrel{\infty}{\leftarrow}$ & $\check{r}$ & $\stackrel{2}{\check{c}}$ \\
\hline & & $\nabla$ & $\bar{m}$ & กn & $\stackrel{N}{E}$ & D্ল & $\hat{\sigma}$ & $\stackrel{m}{m}$ & $\stackrel{\infty}{\infty}$ & $\infty$ & $\stackrel{\infty}{+}$ & पे & 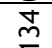 & 于 & 员 & 8 & \& & L \\
\hline & & & $\dot{0}$ & $\dot{0}$ & $\dot{0}$ & $\div$ & $\dot{0}$ & $\dot{0}$ & 0 & 0 & $\dot{0}$ & $\ddot{0}$ & $\check{0}$ & $\dot{0}$ & $\check{0}$ & $\dot{0}$ & & \\
\hline & & in & $\stackrel{n}{r}$ & $\stackrel{m}{m}$ & $\stackrel{m}{r}$ & $\frac{1}{2}$ & ô & $\stackrel{N}{F}$ & 6 & $\underline{n}$ & $\stackrel{\infty}{\stackrel{\infty}{\sim}}$ & $\frac{7}{7}$ & $\stackrel{\infty}{\stackrel{\infty}{\sim}}$ & $\stackrel{n}{5}$ & $\stackrel{\infty}{-}$ & 옫 & ర్ & 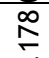 \\
\hline & & & & $\dot{0}$ & $\dot{0}$ & $\dot{0}$ & $\dot{0}$ & $\dot{0}$ & $\dot{0}$ & $\dot{0}$ & $\dot{0}$ & $\dot{0}$ & $\dot{0}$ & $\dot{0}$ & $\circ$ & $\dot{0}$ & & \\
\hline \multirow{8}{*}{ 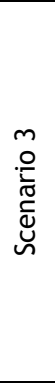 } & \multirow{8}{*}{ 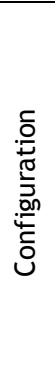 } & - & 움 & 음 & ณू & 음 & \% & ఫั & 望 & ఫั & $\stackrel{\text { p }}{\Gamma}$ & స్ & 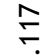 & 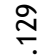 & $\frac{g}{r}$ & $\stackrel{\infty}{\sim}$ & 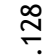 & 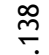 \\
\hline & & $\sim$ & $\hat{\circ}$ & ڤิ & సิ & సे & $\tilde{\tilde{o}}$ & $\tilde{\tilde{o}}$ & $\tilde{\tilde{o}}$ & $\tilde{m}$ & \%ి & ळे & \%ి & ळे & 8 & 8 & 8 & 8 \\
\hline & & & $\frac{\dot{0}}{\dot{y}}$ & $\dot{0}$ & $\dot{0}$ & $\dot{0}$ & $\dot{0}$ & $\dot{0}$ & 0 & 0 & $\dot{0}$ & 10 & $\dot{0}$ & $\frac{0}{a}$ & 0 & $\dot{0}$ & $\frac{\dot{0}}{m}$ & 0 \\
\hline & & $m$ & $\stackrel{m}{\leftarrow}$ & $\stackrel{\text { เn }}{\leftarrow}$ & 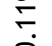 & $\stackrel{m}{m}$ & 0 & $\stackrel{m}{\square}$ & 0 & $\div$ & 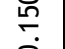 & 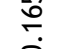 & $\stackrel{m}{\leftarrow}$ & f & $\stackrel{\text { Ln }}{\leftarrow}$ & $\stackrel{\Gamma}{\rightleftarrows}$ & $\stackrel{\nabla}{5}$ & เัก \\
\hline & & $\nabla$ & ᄋ & $\stackrel{\infty}{=}$ & $\hat{\circ}$ & ᄋᄋ & : & เั & 央 & ஜ & 임 & $\stackrel{\infty}{m}$ & $\stackrel{\sigma}{\sigma}$ & ลิ & స్ & 守 & $\stackrel{\infty}{\sim}$ & 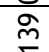 \\
\hline & & & $\check{0}$ & 0 & $\ddot{\circ}$ & $\check{0}$ & $\ddot{0}$ & $\stackrel{0}{0}$ & c & $\stackrel{0}{0}$ & $\dot{0}$ & $\check{0}$ & $\check{0}$ & 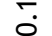 & $\check{0}$ & $\check{0}$ & $\check{0}$ & \\
\hline & & L & ก & ติ & $\stackrel{2}{5}$ & $\stackrel{m}{=}$ & 冓 & 인 & 恶 & ปั & $\infty$ & 돔 & $\infty$ & $\stackrel{\infty}{=}$ & $\widetilde{\infty}$ & ㄴำ & $\widetilde{\infty}$ & ০ \\
\hline & & & 0 & 0 & $0^{\circ}$ & & $\circ$ & 0 & 0 & $c$ & $\check{0}$ & c. & $\check{0}$ & $c$ & $\check{0}$ & $\dot{0}$ & & \\
\hline \multirow{8}{*}{ 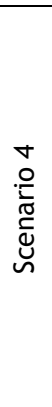 } & \multirow{8}{*}{ 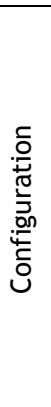 } & - & $\frac{0}{2}$ & E. & 농 & $\frac{\pi}{5}$ & 尔 & ò & స్ & ? & $\stackrel{\hat{m}}{\leftarrow}$ & $\stackrel{m}{c}$ & 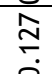 & $\stackrel{\text { m}}{\leftarrow}$ & $\frac{8}{5}$ & $\frac{\pi}{2}$ & $\stackrel{\hat{m}}{\longrightarrow}$ & $\stackrel{\text { 学 }}{5}$ \\
\hline & & $\sim$ & $\infty$ & $\begin{array}{l}\infty \\
\infty\end{array}$ & $\frac{5}{5}$ & 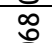 & 产 & m & $\stackrel{n}{n}$ & $\bar{m}$ & 8 & 용 & $\frac{2}{2}$ & ○ & $\delta$ & 5 & $\tilde{0}$ & 5 \\
\hline & & N & $\stackrel{\circ}{\circ}$ & @̊ & $\stackrel{0}{0}$ & 웅 & $\stackrel{0}{0}$ & $\stackrel{0}{\circ}$ & c & 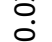 & $\ddot{0}$ & : & 0 & ب. & $\circ$ & $\check{0}$ & 5 & \\
\hline & & $m$ & $\exists$ & స్ & $\stackrel{m}{m}$ & $\stackrel{\text { In }}{\square}$ & 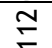 & ป & 8 & $\underset{\Xi}{ \pm}$ & ำ & $\sqrt{N}$ & g & เิ็ & $\stackrel{20}{\circ}$ & $\stackrel{0}{1}$ & เกำ & 는 \\
\hline & & & 5 & 5 & 5 & 5 & 5 & 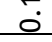 & $\check{0}$ & $\dot{0}$ & $\check{0}$ & $\check{\circ}$ & $\check{0}$ & $\check{\sigma}$ & $\check{0}$ & $\check{0}$ & $\check{\sigma}$ & $c$ \\
\hline & & $\nabla$ & $\stackrel{\infty}{\rightleftharpoons}$ & 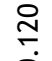 & \%ั & 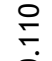 & ळొ & চо. & กิ & ก̂. & 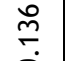 & $\stackrel{\text { gे }}{\square}$ & 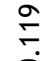 & $\stackrel{\text { m }}{\Gamma}$ & $\underset{7}{7}$ & $\stackrel{\hat{f}}{\leftarrow}$ & $\stackrel{\infty}{\sim}$ & $\stackrel{\infty}{m}$ \\
\hline & & in & $\stackrel{0}{\Sigma}$ & 암 & $\stackrel{0}{\Sigma}$ & $\stackrel{n}{\Sigma}$ & $\stackrel{\infty}{\circ}$ & $\overline{\check{I}}$ & $\stackrel{\infty}{\circ}$ & 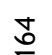 & $\bar{\infty}$ & 도 & $\bar{\infty}$ & $\stackrel{\infty}{\Sigma}$ & $\cong$ & in & $\infty$ & $\bar{\infty}$ \\
\hline & & & & $\dot{0}$ & $\dot{0}$ & $\check{0}$ & $\overline{0}$ & $\check{0}$ & $\overline{0}$ & $\check{0}$ & $\check{0}$ & $\dot{0}$ & $\check{0}$ & $\dot{0}$ & $\overline{0}$ & $\check{0}$ & \ulcorner & $c$ \\
\hline
\end{tabular}


Table 6: Set of weights and ranking order of alternative configurations

\begin{tabular}{|l|l|}
\hline Set of weights & Alternative configurations in ranking order \\
\hline Set1: equal weights for all performance measures & Config5, Config3, Config4, Config1, Config2 \\
\hline Set2: major weight for system utilisation & Config3, Config4, Config5, Config1, Config2 \\
\hline Set3: major weight for system output rate & Config5, Config3, Config4, Config1, Config2 \\
\hline Set4: unequal weights for performance measures & Config5, Config3, Config1, Config4, Config2 \\
\hline
\end{tabular}

\section{CONCLUSION}

The reconfiguration of manufacturing systems caters for varying market or production and operation management conditions. But any change from an old to a new manufacturing set-up without prior evaluation is risky. In such cases, the alternatives generally need to be evaluated on multiple performance parameters. As presented here, an industry was interested in reconfiguring its present manufacturing configuration to satisfy dynamic competitive market requirements. Their operation managers identified suitable alternatives to the present manufacturing configuration. This work was presented to convince them that the assessment of these alternatives needs to take multiple performance criteria into account. So there is a need to identify and apply an approach to assess alternative configurations. For the case in hand, the industry managers had the maximisation of system utilisation, the minimisation of total cycle time, the maximisation of delivery prior to due time, the minimisation of delivery lateness, and the minimisation of products waiting prior to processing, inspection and move as their performance objectives. A multi-criteria decision-making grey relational analysis approach was used to evaluate manufacturing configurations. Using a simulation tool, the alternative manufacturing configurations were made to work under different demand and operational scenarios. Concepts such as performance weights, prioritisation of product to load machines, the arrival rate of customers, and their product mix demand made the approach more sensitive.

It was revealed that there is a need to reconfigure the present manufacturing configuration in response to the dynamic demand to stay competitive in the market. By assessing alternative configurations using a grey relational approach, decision-makers decided to reconfigure their present manufacturing configuration. But the reconfiguration choice set reduced to Config5 and Config3 if they set the major preference weights to customer demand satisfaction in terms of time and quantity. However, if the preference was to maximise system utilisation, their reconfiguration choice set shifted to Config3 and Config4. There is a need to bring the cost and the risk associated with reconfiguration into this presented approach in any future investigation. Another interesting aspect could be the development of a model to incorporate real-time criteria for manufacturing system reconfiguration.

\section{ACKNOWLEDGEMENTS}

The author is grateful to the Raytheon Chair for Systems Engineering for funding. The author thanks and acknowledges the support of the Department of Industrial Engineering, College of Engineering, King Saud University, Riyadh.

\section{REFERENCES}

[1] Lee, G.H. 1997. Reconfigurability consideration design of components and manufacturing systems, Int J Adv Manuf Technol, 13, pp.376-386.

[2] Koren, Y., Wang, W. and Gu, X. 2016. Value creation through design for scalability of reconfigurable manufacturing systems, International Journal of Production Research, pp.1-16. DOI:10.1080/00207543.2016.1145821.

[3] Valente, A., Mazzolini, M. and Carpanzano, E. 2015. An approach to design and develop reconfigurable control software for highly automated production systems, International Journal of Computer Integrated Manufacturing, 28(3), pp.321-336.

[4] Koren, Y. and Shpitalni, M. 2010. Design of reconfigurable manufacturing systems, Journal of Manufacturing Systems, 29(4), pp.130-141.

[5] Wang, W. and Koren, Y. 2012. Scalability planning for reconfigurable manufacturing systems, Journal of Manufacturing Systems, 31(2), pp.83-91.

[6] Ahmed, M.D. and ElMaraghy, W. 2005. Investigating optimal capacity scalability scheduling in reconfigurable manufacturing system, Int J Adv Manuf Technol, 52(1), pp.174-193. 
[7] Elmasry, S.S., Youssef, A.M. and Shalaby, M.A. 2015. A cost-based model to select best capacity scaling policy for reconfigurable manufacturing systems, International Journal of Manufacturing Research, 10(2), pp.162-183.

[8] Padayachee, J. and Bright, G. 2012. Modular machine tools: Design and barriers to industrial implementation, Journal of Manufacturing Systems, 31(2), pp.92-102.

[9] Bi, Z.M., Wang, L. and Lang, S.Y.T. 2007. Current status of reconfigurable assembly systems, International Journal of Manufacturing Research, 2(3), pp.303-327.

[10] Fu-Shiung, H. 2009. Collaborative reconfiguration mechanism for holonic manufacturing systems, Automatica, 45(11), pp.2563-2569.

[11] Fu-Shiung, H. and Chiang, C. Y. 2011. Collaborative composition of processes in holonic manufacturing systems, Computers in Industry, 62(1), pp.51-64.

[12] Garbie, I.H. 2014. Performance analysis and measurement of reconfigurable manufacturing systems, Journal of Manufacturing Technology Management, 25(7), pp.934-957. http://dx.doi.org/10.1108/JMTM07-2011-0070.

[13] Renna, P. and Ambrico, M. 2015. Design and reconfiguration models for dynamic cellular manufacturing to handle market changes, International Journal of Computer Integrated Manufacturing, 28, no. 2, pp. 170-186, doi: 10.1080/0951192X.2013.874590.

[14] Bi, Z.M., Lang, Z.Y.T., Zen, W. and Wang, L. 2008. Reconfigurable manufacturing systems: The state of the art, International Journal of Production Research, 46(4), pp.967-992.

[15] Rehman, A.U. and Babu, A.S. 2013. Reconfigurations of manufacturing systems - An empirical study on concepts, research and applications, Int J Adv Manuf Technol, 66(1-4), pp.107-124.

[16] Tang, Y., Bi, Z.M. and Qiu, R.G. 2004. Integrated design approach for virtual production line-based reconfigurable manufacturing systems, International Journal of Production Research, 42(18), pp.38033822.

[17] Landers, R.G., Min, B.K. and Koren, Y. 2001. Reconfigurable machine tools, CIRP Annals-Manufacturing Technology, 50(1), pp.269-274.

[18] Schmidt, K.W. 2015. Computation of supervisors for reconfigurable machine tools, Discrete Event Dynamic Systems, 25(1-2), pp.125-158.

[19] Bi, Z.M. and Wang, L. 2009. Optimal design of reconfigurable parallel machining systems, Robotics and Computer Integrated Manufacturing, 25(6), pp. 951-961.

[20] Váncza, J., Monostori, L., Lutters, D., Kumara, S.R., Tseng, M., Valckenaers, P. and Van Brussel, H. 2011. Cooperative and responsive manufacturing enterprises, CIRP Annals-Manufacturing Technology, 60(2), pp.797-820.

[21] Fu-Shiung, H. 2010. Design of reconfiguration mechanism for holonic manufacturing systems based on formal models, Engineering Applications of Artificial Intelligence, 23(7), pp.1187-1199.

[22] Qiu R.G., Russell D.W., McDonnell, P. and Joshi, S. 2005. A heuristic game theoretic approach to resource sharing in reconfigurable manufacturing, Int J Adv Manuf Technol, 25, pp.78-87. DOI 10.1007/s00170-0031861-1.

[23] Dou, J., Dai, X. and Meng, Z. 2011. A GA-based approach for optimizing single-part flow-line configurations of RMS, Journal of Intelligent Manufacturing, 22(2), pp.301-317.

[24] Francalanza, E., Borg, J.C. and Constantinescu, C. 2016. A fuzzy logic based approach to explore manufacturing system changeability level decision, Procedia CIRP, 41, pp.3-8.

[25] Kristianto, Y., Gunasekaran, A. and Jiao, J. 2014. Logical reconfiguration of reconfigurable manufacturing systems with stream of variations modeling: A stochastic two-stage programming and shortest path model, International Journal of Production Research, 52(5), pp.1401-1418.

[26] Rehman, A.U., Al-Ahmari, A.M.A. and Gunasekaran, A. 2011. Evaluation of advance manufacturing technologies using concord and discord indices, International Journal of Computer Integrated Manufacturing, 24(4), pp.328-337.

[27] Jenab, K., Sarfaraz, A., Weinsier, P.D., Moeini, A. and Al-Ahmari, A.M.A. 2015. i-DEMATEL method for integrated manufacturing technology selection, Journal of Manufacturing Technology Management, 26(3), pp.349-363.

[28] Maniraj, M. and Pakkirisamy, V. 2015. Justification of reconfigurable manufacturing systems selection using extended Brown-Gibson model and fuzzy TOPSIS, International Journal of Industrial and Systems Engineering, 20(1), pp.1-21.

[29] Taha, Z. and Rostam, S. 2012. A hybrid fuzzy AHP-PROMETHEE decision support system for machine tool selection in flexible manufacturing cell, Journal of Intelligent Manufacturing, 23(6), pp.2137-2149.

[30] Figueira, J., Mousseau, V. and Roy, B. 2005. ELECTRE methods. In Multiple criteria decision analysis: State of the art surveys (pp.133-153), New York: Springer.

[31] Hatami-Marbini, A. and Tavana, M., 2011. An extension of the Electre I method for group decision-making under a fuzzy environment, Omega, 39(4), pp.373-386.

[32] Galan, R., Racero, J., Eguia, I. and Garcia, J.M. 2007. A systematic approach for product families formation in reconfigurable manufacturing systems, Robotics and Computer-Integrated Manufacturing, 23(5), pp.489-502.

[33] Abbasi, M. and Houshmand, M. 2010. Production planning and performance optimization of reconfigurable manufacturing systems using genetic algorithm, Int J Adv Manuf Technol, 54(1-4), pp.373-392. DOI 10.1007/s00170-010-2914-x.

[34] Harrell, C.R., Ghosh, B.K. and Bowden, R.O. 2011. Simulation using ProModel, $3^{\text {rd }}$ ed., McGraw-Hill Science/Engineering/Math, ISBN: 0-07-234144-0. 
[35] De Boer, L., Labro, E. and Morlacchi, P. 2001. A review of methods supporting supplier selection, European Journal of Purchasing \& Supply Management, 7(2), pp.75-89.

[36] Vincent, F.Y. and Hu, K.J. 2010. An integrated fuzzy multi-criteria approach for the performance evaluation of multiple manufacturing plants, Computers \& Industrial Engineering, 58(2), pp.269-277.

[37] Vaidya, O.S. and Kumar, S. 2006. Analytic hierarchy process: An overview of applications, European Journal of Operational Research, 169(1), pp.1-29.

[38] Chen, S.Y. 1998. Engineering fuzzy set theory and application, Beijing: State Security Industry Press.

[39] Wang, T.C. and Chang, T.H. 2007. Application of TOPSIS in evaluating initial training aircraft under a fuzzy environment, Expert Systems with Applications, 33(4), pp.870-880.

[40] Dağdeviren, M. 2008. Decision making in equipment selection: An integrated approach with AHP and PROMETHEE, Journal of Intelligent Manufacturing, 19(4), pp.397-406.

[41] Xu, X. 2001. The SIR method: A superiority and inferiority ranking method for multiple criteria decision making, European Journal of Operational Research, 131(3), pp.587-602, ISSN 0377-2217, http://dx.doi.org/10.1016/S0377-2217(00)00101-6.

[42] Tong, L.-I., Su, C.-T. and Wang, C.-H. 1997. The optimization of multi-response problems in the Taguchi method, International Journal of Quality \& Reliability Management, 14(4), pp.367-380.

[43] Lin, J.L. and Tarng, Y.S. 1998. Optimization of the multi-response process by the Taguchi method with grey relational analysis, Journal of Grey Systems, 4(4), pp.355-370.

[44] Wen, K.L. 2004. Grey systems. Tucson, USA: Yang's Scientific Press.

[45] Huang, J.T. and Liao, Y.S. 2003. Optimization of machining parameters of wire-EDM based on grey relational and statistical analyses, International Journal of Production Research, 41, pp.1707-1720.

[46] Sood, A.K., Ohdar, R.K. and Mahapatra, S.S. 2010. Parametric appraisal of fused deposition modelling process using the grey Taguchi method, Proceedings of the Institution of Mechanical Engineers, Part B, Journal of Engineering Manufacture, 223, pp.135-145.

[47] Tarang, Y.S., Juang, S.C. and Chang, C.H. 2002. The use of grey based Taguchi methods to determine submerged arc welding process parameters in hardfacing, Journal of Material Processing Technology,128, pp.1-6.

[48] Chiadamrong, N. 1999. An integrated fuzzy multi-criteria decision-making method for the manufacturing strategies selection, Comput. Indust. Eng., 37, pp.433-436.

[49] Chan, J.W.K. and Tong, T.K.L. 2007. Multi-criteria material selections and end-of-life product strategy: Grey relational analysis approach, Materials \& Design, 28(5), pp.1539-1546.

[50] Chan, J.W.K. 2008. Product end of life OPTIONS selection: Grey relational analysis approach, International Journal of Production Research, 46(11), pp-2889-2912.

[51] Saltelli, A., Tarantola, S., Campolongo, F. and Ratto, M. 2004. Sensitivity analysis in practice. New York: Wiley. 